\title{
METASTASIS OTAK TIPE MILIER PADA KASUS ADENOKARSINOMA PARU DENGAN MUTASI EGFR T790M
}

\author{
MILIARY TYPE BRAIN METASTASES IN LUNG ADENOCARCINOMA WITH \\ EGFR T790M MUTATION
}

I Made Oka Adnyana*, Ni Luh Putu Eka Arisanti**

\section{ABSTRACT}

Brain metastasis is the most common intracranial tumor with the number of events exceeding primary brain tumors. It still holds high mortality and morbidity rate to date. Most of the metastases are macroscopic parenchymal mass lesions with surrounding edema and occurred in the gray-white matter junction. Miliary brain metastasis is a rare condition with generally poor prognosis.

A male patient, 51 years old, Balinese, was admitted with decreasing consciousness since 1 week ago. The patient was diagnosed with lung adenocarcinoma with positive EGFR mutation in March 2019 and since April 2019 was started taking gefitinib 200mg every 24 hours. The patient also had intermittent headaches accompanied by vomiting, the head MRI with contrast showed multiple-miliary punctate lesions on almost every brain tissue, suggesting miliary type metastases. Further investigation revealed a positive EGFR T790M mutation.

Miliary type brain metastases is a rare condition with poor prognosis. Chemotherapy and radiotherapy do not provide a satisfactory result. Miliary metastases pattern should be considered in differential diagnoses of patients with progressive dementia and multiple lesions as numerous diseases have similar head CT scan appearances. To this date, there is no standard therapy regimen for miliary brain metastases but some studies showed that the combination of wholebrain radiotherapy and EGFR tyrosine kinase inhibitor was deemed as having beneficial effects. The survival rate on these cases range from 14 days to 24 months.

Keywords: Adenocarcinoma, brain, lung, metastases, miliary type

\section{ABSTRAK}

Metastasis otak menempati tumor intrakranial yang paling sering terjadi yang insidensinya melebihi tumor otak primer. Hingga kini metastasis otak masih memiliki tingkat morbiditas dan mortalitas tinggi. Sebagian besar metastasis merupakan lesi massa parenkimal makroskopis dengan edema di sekitarnya, dan terjadi pada gray-white matter junction. Metastasis otak tipe milier merupakan kondisi yang jarang dijumpai dengan prognosis yang umumnya buruk.

Pasien laki-laki, 51 tahun, dirawat dengan keluhan kesadaran menurun sejak 1 minggu sebelum ke rumah sakit. Pasien didiagnosis dengan adenokarsinoma paru EFGR positif sejak bulan Maret 2019 dan sejak April 2019 memulai pengobatan dengan gefitinib 200mg tiap 24 jam. Pasien juga mengalami nyeri kepala yang hilang timbul disertai dengan muntah. Pemeriksaan MRI kepala kontras ditemukan adanya lesi punktat multipel-milier menyebar pada hampir seluruh bagian otak, mengesankan suatu metastasis tipe milier. Pemeriksaan lanjutan terhadap mutasi EGFR T790M menunjukkan hasil yang positif

Metastasis otak tipe milier merupakan kondisi yang jarang dijumpai dengan prognosis yang umumnya buruk. Kemoterapi dan radioterapi hasilnya tidak memuaskan. Pola metastasis tipe milier harus dipertimbangkan dalam diagnosis diferensial pasien dengan demensia progresif dan lesi multipel dikarenakan beberapa penyakit mempunyai gambaran hasil CT scan kepala yang mirip. Hingga kini belum terdapat regimen terapi standar untuk metastasis otak tipe milier namun hasil penelitian menunjukkan kombinasi whole brain radiotherapy dan EGFR tyrosine kinase inhibitor dipandang dapat memberi efek yang menguntungkan. Harapan hidup pada kasus-kasus ini berkisar antara 14 hari sampai 24 bulan.

Kata kunci: Adenokarsinoma, metastasis, otak, paru, tipe milier

*Departemen Neurologi FK Universitas Udayana/RSUP Sanglah, Denpasar. **Departemen Pulmonologi FK FK Universitas Udayana/ RSUP Sanglah, Denpasar. Korespondensi: okaadnyanadrsps@yahoo.com.

\section{PENDAHULUAN}

Metastasis otak menempati tumor intrakranial yang paling sering melebihi tumor primer otak. Insidensinya lebih banyak sekitar 3-10 kali lipat dibanding tumor primer otak setiap tahunnya. ${ }^{1}$

Tumor primer yang paling sering metastasis ke otak pada pasien dewasa yaitu paru (36-64\%), payudara (15-25\%), melanoma (5-20\%), dan yang tidak diketahui tumor primernya sebesar $10-15 \%$. Patofisiologi dari proses penyebaran atau metastasis tumor yaitu migrasi dari sel tumor, dari asal ke pembuluh darah, tertahannya sel tumor di pembuluh darah oleh eksklusi ukuran, proses ekstravasasi aktif diikuti proliferasi perivaskular dan angiogenesis. 
Sebagian besar metastasis merupakan lesi massa parenkimal makroskopis dengan edema di sekitarnya, dan terjadi pada gray-white matter junction. Metastasis otak tipe milier merupakan kondisi yang jarang dijumpai dengan prognosis yang umumnya buruk. Dari keseluruhan tumor otak metastasis hanya $5 \%$ diantaranya yang memiliki 5 atau lebih lesi metastasis milier. ${ }^{2}$

Manifetasi klinis dari metastasis tumor ke otak yang paling umum dijumpai yaitu nyeri kepala, yang dirasakan pada 40-50 persen pasien, di samping itu dapat dijumpai adanya defisit neurologis fokal, gangguan kognitif, kejang hingga stroke. ${ }^{1}$

Metastasis otak milier biasanya tidak bergejala dan gejalanya berbeda dari pasien ke pasien. Variabilitas gejala awal dari metastasis tipe milier dapat meliputi sindrom serebellar, defisit motorik maupun sensorik dan adanya gangguan kognitif. ${ }^{2-3}$ Sebagian pasien dapat menunjukkan gejala sindrom mental organik, demensia subakut, hemiparesis dan konvulsi. Demensia onset dini yang berkembang secara cepat dapat menjadi tanda dari patologi metastasis tipe ini. Abnormalitas bicara, gangguan berjalan dapat menjadi gejala awal metastasis otak tipe milier dan dapat pula diketahui secara insidental dalam pemeriksaan radiologis. ${ }^{3}$

Kami melaporkan satu kasus pasien dengan adenokarsinoma paru dengan mutasi EGFR delesiekson 19 dan T790M pada ekson 20 dengan adanya defisit neurologis global dan fokal yang kemudian diketahui mengalami metastasis otak tipe milier berdasarkan radiologi diagnostik MRI kepala dengan penyangatan gadolinium.

\section{KASUS}

Pasien laki-laki, 51 tahun, suku Bali, dirawat di RSUP Sanglah sejak tanggal 28 Oktober 2019 dengan keluhan penurunan kesadaran sejak 1 minggu sebelum masuk rumah sakit. Pada pemeriksaan awal, pasien tampak mengantuk, tidak dapat berkomunikasi dan tidak dapat mengikuti perintah. Sebelumnya pasien bekerja sebagai supir angkutan online dan pengrajin fiber glass, terakhir aktif bekerja 1 bulan lalu, tidak ada riwayat merokok, konsumsi alkohol dan pasien rajin melakukan aktivitas olahraga yoga.

Pasien sebelumnya dirawat di rumah sakit swasta di Denpasar dan didiagnosis dengan adenokarsinoma paru EFGR (+) sejak bulan Maret 2019 dan sejak April 2019 memulai pengobatan dengan iressa (gefitinib) 200mg tiap 24 jam. Hasil CT scan thoraks pada bulan Maret 2019 tercantum pada (Gambar 1), dengan bacaan adanya konsolidasi pada lobus inferior paru kiri dan dan tanda penyebaran limfangitik pada paru kanan dan kiri serta nodulnodul pada paru kanan.

Pada akhir September 2019 pasien mengeluhkan adanya pandangan kabur dan kelemahan pada seluruh tubuh. Pasien pergi ke dokter saraf dan

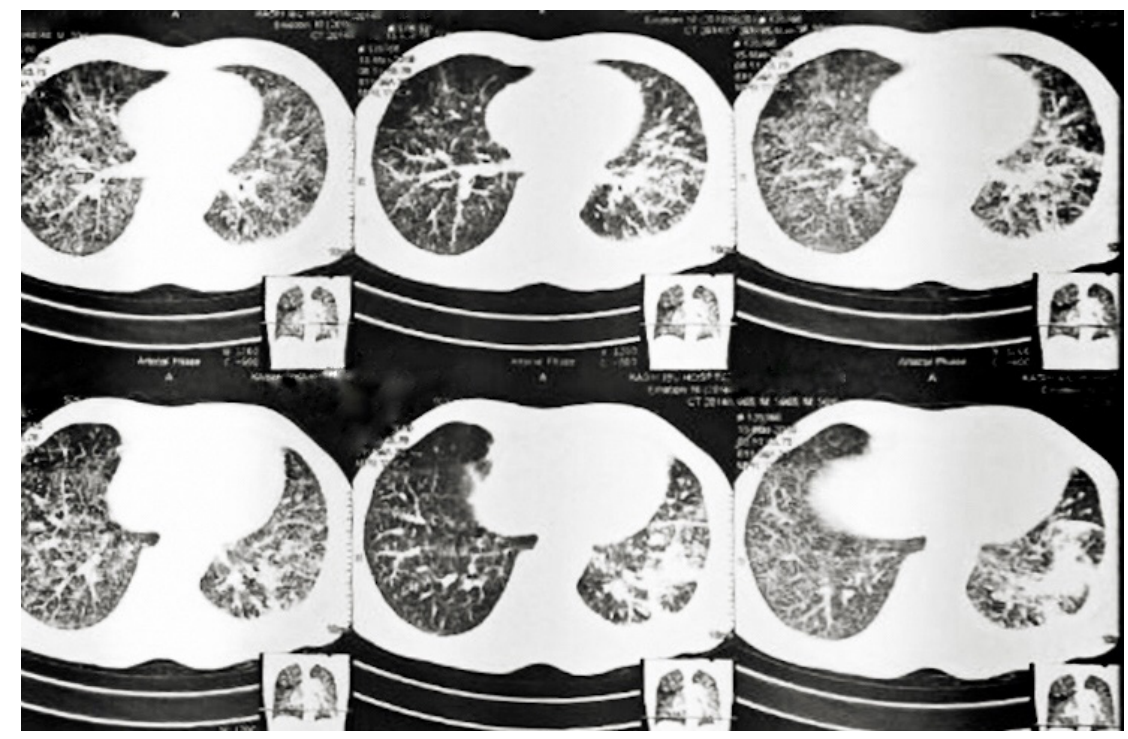

Gambar 1. CT Scan Thoraks Pasien Bulan Maret 2019 


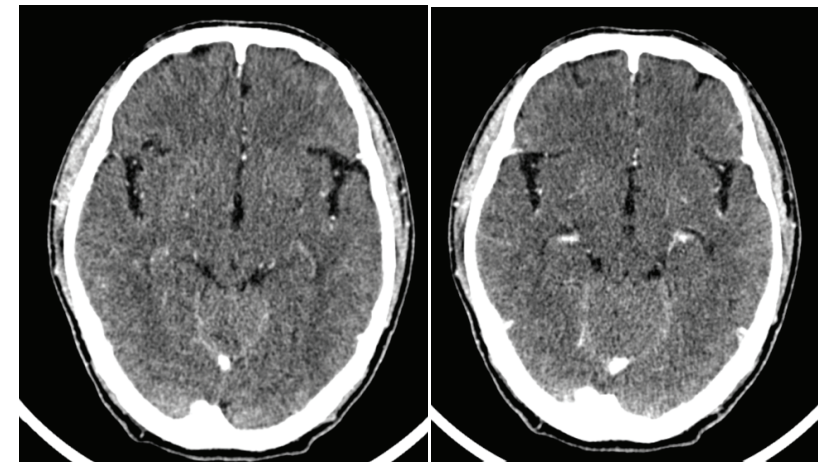

Gambar 2. CT Scan Kepala Kontras Pasien

dilakukan pemeriksaan CT scan kepala dengan hasil CT scan kepala yang tercantum pada (Gambar 2) yang menunjukkan tidak didapatinya suatu kelainan.

Pasien mengalami nyeri kepala dimana awalnya bersifat hilang timbul dan masih membaik dengan pemberian analgetika, namun demikian nyeri kepala semakin lama semakin memberat disertai dengan muntah, dengan sisi tubuh kanan pasien menjadi lemah dan pasien mengalami kesulitan berkomunikasi. Dilakukan pemeriksaan MRI kepala dengan kontras dan didapat hasil adanya lesi multipel punctate-milier hiperintens T1 T2 TIRM, DWI ADC Tra Hemo, intrakranial, supra dan infratentorial, intraserebral intraksial menyeluruh pada area kortikal-subkortikal-white matter, ganglia basal bilateral, corpus callosum, seluruh bagian intraserebral, serebellar, mesensefalons, pons dan batang otak (Gambar 3). Lesi berbatas tegas, tidak tampak area edema perifokal atau efek massa dan menyangat dengan pemberian kontras intravena gadolinium. Gambaran tersebut sesuai dengan proses metastasis intrakranial generalisata penyebaran hematogenik atau metastasis tipe milier. Dengan adanya kecurigaan suatu progresifitas dari adenokarsinoma paru yang diderita pasien, dilakukan pengecekan terhadap mutasi T790M dan didapatkan hasil positif pada ekson 20, di samping itu pasien sebelumnya telah ditegakan EGFR (+) untuk delesi ekson 19.

Pasien akhirnya dirujuk ke RSUP Sanglah untuk tata laksana lebih lanjut. Selama dirawat pasien mendapatkan obat anti edema golongan steroid, kesadaran pasien berangsur membaik, namun pasien tetap mengalami kondisi bradifrenia, Pemeriksaan fungsi kognitif dan memori pasien belum dapat dilaksanakan dikarenakan atensi pasien yang belum baik.

Pasien dipulangkan dari rumah sakit dengan Karnofsky Performance Scale 40-50 dan dijadwalkan untuk whole brain radiotherapy (WBRT) bersama pula dengan pemberian tyrosine kinase inhibitors. Dalam tiga hari pasien di rumah, kondisi pasien kembali mengalami perburukan. Pasien dirawat kembali di rumah sakit dengan kontak yang memburuk dan sulit asupan per oral. Kesadaran pasien pada saat itu E4V4M5, pasien dijadwalkan mendapat WBRT dengan rencana fraksi 2 Grey sebayak 20 siklus.

Pasien sempat menjalankan 1 siklus WBRT, akan tetapi kondisi pasien semakin menurun dengan kesadaran menurun, demam dan sesak nafas Pasien mengalami komplikasi hospital acquired pneumonia dan mendapatkan terapi antibiotika. Pada akhirnya pasien dinyatakan meninggal dunia setelah 7 hari perawatan kembali di rumah sakit.

\section{PEMBAHASAN}

Metastasis merupakan tumor otak yang paling sering dijumpai, $40 \%$ neoplasma otak berasal dari metastasis. Sebagian besar metastasis merupakan lesi massa parenkimal makroskopis dengan edema di sekitarnya, dan terjadi pada gray-white matter junction. Karsinomatosis leptomeningeal yang berasal dari infiltrasi difus pada spasium subarakhnoid terjadi pada $3 \%$ pasien dengan karsinoma paru, payudara, lambung. Di sisi lain terdapat bentuk yang langka dari metastasis otak dimana terjadi penyebaran otak pada spasium perivaskuler VirchowRobin, parenkim dan juga meninges, disebut dengan 


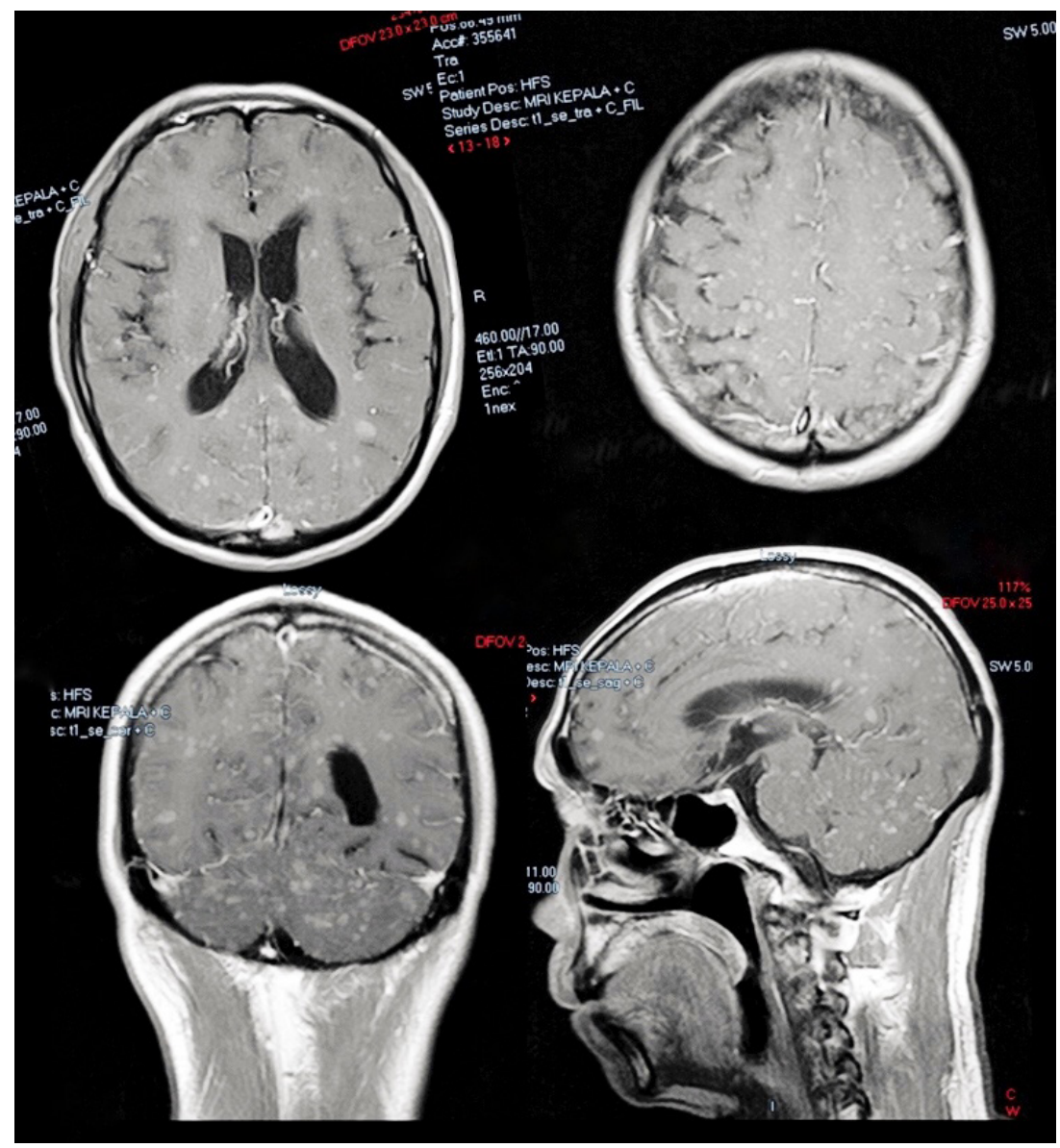

Gambar 3. MRI Kepala Kontras Menunjukkan Lesi Multipel Punctate-Milier Hiperintens

"miliary carcinoma", "miliary brain metastases", "metastatic meningoencephalic carcinomatosis without tumefaction".2

Metastasis otak milier merupakan kondisi yang langka dengan prognosis yang umumnya buruk. Metastasis otak milier biasanya tidak bergejala dan gejalanya berbeda dari pasien ke pasien. Beberapa dapat menunjukkan gejala sindrom mental organik, demensia subakut, hemiparesis dan konvulsi. Onset yang dini dari demensia yang berkembang secara cepat dapat menjadi tanda dari patologi metastasis tipe ini., ${ }^{2,4}$

Beberapa jenis tumor menunjukkan pola penyebaran spesifik organ tertentu. Ketika sel metastatik kanker memasuki sirkulasi darah, sel kanker tersebut dapat tertambat pada aliran darah yang lambat pada anyaman kapiler percabangan pembuluh darah. Sel-sel kanker yang tertambat tersebut menginvasi sel endothelial pembuluh darah otak dan dapat memicu pertumbuhan dan invasi tumor metastasis. Baru-baru ini ditemukan peranan dari molekul adhesi selular dalam proses metastasis. Dalam sebuah studi disebutkan bahwa dalam kasus metastasis otak tipe milier molekul adhesi diekspresikan secara abnormal sehingga dapat memerangkap sel tumor dalam pembuluh darah. Terdapat hipotesis bahwa lapisan adventisia atau pial perivaskular memegang peranan penting dalam perkembangan metastasis otak tipe milier. ${ }^{4}$

Pada pasien yang kami laporkan, pasien awalnya menunjukkan adanya penurunan kesadaran, adanya keluhan nyeri kepala, kelemahan separuh tubuh kanan yang membaik, dan bradifrenia sehingga pemeriksaan fungsi memori dan kognitif masih sulit untuk dilaksanakan.

Berdasarkan literatur berbahasa inggris, ditemukan 25 kasus saja yang dilaporkan dengan metastasis otak tipe milier. Survival secara keseluruhan dilaporkan dapat mencapai 24 bulan namun dapat pula sependek 14 hari sejak diagnosis awal. ${ }^{2}$ Dalam kasus yang kami dapatkan, pasien akhirnya meninggal dalam waktu 1 bulan sejak awal terdiagnosis dengan metastasis otak tipe milier. 
Foto polos kepala dan CT scan memiliki nilai diagnostik sangat terbatas pada metastasis otak milier. CT scan kepala dengan kontras dapat menunjukkan lesi-lesi kecil. Edema otak dari lesi metastasis multipel dapat nampak pada CT scan. Hidrosefalus yang muncul karena kerusakan meninges dan periventrikular yang mengganggu sirkulasi likuor serebrospinalis dapat terdeteksi pada CT non kontras. ${ }^{2,5}$

MRI terbukti lebih efektif dari CT untuk deteksi patologi SSP, sehingga teknik pencitraan ini menggunakan kontras dipilih untuk mengevaluasi metastasis pada otak dan medulla spinalis. Metastasis milier nampak sebagai lesi nodular, ukuran kecil, multipel dengan penyebaran perivaskular yang umumnya berintensitas iso-rendah pada $\mathrm{T} 1$ dan intensitas tinggi pada T2-weighted, dapat nampak penyangatan nodular atau periferal (ring-like) dengan injeksi gadolinium. ${ }^{5,7}$ Lesi milier dapat pula tidak nampak pada MRI dan tidak menyangat kontras. MRI kontras dapat gagal delineasi lesi metastasis karena masih intaknya sawar darah otak pada stadium awal perjalanan klinis. ${ }^{8}$

CT scan pada kasus ini tidak menunjukkan adanya suatu kelainan dimana setelah dilakukan pemeriksaan MRI kepala dengan kontras teramati adanya lesi punctate-milier hiperintens T1 T2 DWI intrakranial, supra dan infratentorial, intraserebral intra aksial menyeluruh yang menyangat dengan pemberian kontras gadolinium.

Diagnosis diferensial dari adanya lesi milier pada otak dalam pencitraan radiologis diantaranya adalah Tuberkulosis milier, Neurosistiserkosis, dan Toksoplasmosis. Pemeriksaan canggih seperti proton MR spectroscopy (MRS) merupakan instrumen yang poten untuk menganalisa metabolisme jaringan secara noninvasive. MRS menunjukan perubahan konsentrasi metabolit intraseluler seperti choline (Cho), kreatinin (Cr), N-acetylaspartate (NAA), lipid, dan laktat pada jaringan patologis. Teknik ini dapat membedakan jaringan patologis dengan jaringan normal otak dalam hal perbedaan metabolit intraseluler. ${ }^{2,7}$ Biopsi otak hingga kini masih menjadi teknik diagnostik standar dalam membedakan lesi neoplastik dan non-neoplastik. Biopsi otak dilanjutkan pemeriksaan patologis pada kasus metastasis otak milier dapat dilakukan dengan metode pembedahan stereotaktik. ${ }^{6}$

Prognosis metastasis otak milier umumnya buruk, kemoterapi atau radioterapi tidak memberikan efek yang signifikan. Belum ditemukan regimen terapi standar hingga saat ini. Radiasi otak whole brain 300 Gy per fraksi sebanyak 10 fraksi merupakan standar terapi untuk pasien dengan metastasis otak, terutama pasien dengan status performa yang buruk. ${ }^{2}$

Gefitinib, tyrosine kinase inhibitor EGFR molekul kecil memiliki aktivitas antitumor signifikan pada advanced non-small-cell lung carcinoma (NSCLC). Gefitinib dapat membuat regresi radiologis dan klinis yang dramatis pada $10 \%$ pasien dengan NSCLC. Respons parsial dengan gefitinib berhubungan dengan sensitivitas mutase EGFR. EGFR TKI dipandang dapat memiliki efek yang menguntungkan dalam terapi metastasis otak milier. Hasil studi menunjukkan bahwa kombinasi whole brain radiation dan gefitinib merupakan satu-satunya terapi untuk metastasis otak milier hingga saat ini. ${ }^{2,9}$ Respons parsial dengan penggunaan gefitinib berhubungan dengan sensitivitas mutasi dari EGFR.

Mutasi yang terkait sensitivitas terhadap EGFR-TKI biasanya terletak pada ekson 19 dan 21, mutasi pada ekson 20 dapat berasosiasi dengan sensitivitas atau resistensi terhadap TKI. ${ }^{3}$ Generasi ketiga EGFR TKI osimertinib merupakan inhibitor yang poten dan bersifat ireversibel terhadap EGFR dan juga T790M, yang merupakan mutasi pemicu resistensi tersering pada pasien yang diterapi dengan lini pertama EGFR-TKI. ${ }^{10}$ Pertimbangan pengalihan targeted agent pada kasus ini perlu dilakukan mengingat pasien positif terdeteksi memiliki mutasi pada ekson 20 T790M dalam upaya peningkatan angka survival jika terapi EFGR TKI dikombinasikan dengan WRBT. ${ }^{2}$

Suatu studi di Korea pada tahun 2018 menunjukkan bahwa mutasi T790M yang didapat dijumpai lebih sering pada pasien dengan mutasi delesi ekson 19 dan pada pasien dengan jangka waktu pengobatan EGFR-TKI yang lebih lama. Analisa 
lebih lanjut memberikan hasil asosiasi T790M dengan prognosis yang baik dipengaruhi oleh pemberian terapi osimertinib. Osimertinib merupakan faktor prognostik independen terhadap kesintasan secara keseluruhan, kesintasan pascaprogresi dan kesintasan bebas metastasis otak pada analisa multivariat. ${ }^{11}$

Adenokarsinoma dengan pola metastasis milier baru-baru ini diduga sebagai suatu subtipe yang khas yang utamanya ditemukan pada pasien yang tidak pernah merokok dan terkait dengan tipe mutasi EGFR delesi ekson 19. ${ }^{12-13}$ Pada kasus ini pasien didiagnosis adenokarsinoma paru mutasi EGFR delesi ekson 19 dan mutasi T790M dengan metastasis otak tipe milier dimana pasien tidak pernah memiliki riwayat merokok.

Diagnosis diferensial dari metastasis otak tipe milier berdasarkan gambaran radiologis diantaranya adalah neurosistiserkosis dan suatu tuberkuloma otak. ${ }^{4}$ Untuk menyingkirkan adanya suatu neurosistiserkosis telah dilakukan pengecekan feses lengkap dan tidak didapatkan adanya telur cacing (taenia). Kista subkutan yang umumnya dijumpai pada separuh kasus sistiserkosis juga tidak didapatkan pada kasus yang kami laporkan. Dengan tidak ditunjangnya klinis yang mengarah pada suatu neurosistiserkosis pemeriksaan serologi terhadap sistiserkosis tidak dilakukan pada kasus pasien ini.

Tuberkuloma pada otak juga merupakan salah satu diagnosis banding metastasis milier pada otak. Namun demikian pada kasus yang kami laporkan, tidak didapatkan tanda dan gejala infeksi tuberkulosis. Pemeriksaan foto thoraks yang telah dilakukan pada pasien tidak menunjukkan adanya kecurigaan ke arah tuberkulosis paru. Pungsi lumbal telah dilakukan dan tidak didapatkan adanya tanda infeksi sistem saraf pusat, serta hasil pemeriksaan gene Xpert tuberkulosis terhadap cairan serebrospinal menunjukkan hasil yang negatif. Di samping itu tidak dijumpai pula adanya sel neoplastik pada pemeriksaan sitologi cairan serebrospinal.

\section{KESIMPULAN}

Metastasis otak tipe milier merupakan kondisi yang jarang dijumpai. Pemeriksaan MRI kepala kontras harus dipertimbangkan pada semua pasien keganasan, dengan defisit neurologis dan hasil CT scan kepala yang normal. Prognosis metastasis otak milier umumnya buruk, dimana kemoterapi atau radioterapi memberi efek yang tidak signifikan.

\section{DAFTAR PUSTAKA}

1. Aninditha T, Andriani R, Malueka RG. Buku ajar neuroonkologi. Kelompok Studi Neuro-onkologi: Perdossi. 2019. h. 200-2.

2. Tripathi K, Tripathi R. Rare presentation of miliary brain metastasis in absence of typically associated mutation. J Neurol Neurophysiol. 2017;8:1000447.

3. Reiter FP, Jung CG, Dorostkar MM, Wagner BE, Denk GU, Heck S dkk. Miliary pattern of brain metastases-a case report of a hyperacute onset in a patient with malignant melanoma documented by magnetic resonance imaging. Reiter dkk. Radiat Oncol. 2015;10:148.

4. Liu S, Zhou X, Wang Y, Liu Y. Miliary metastases in lung cancer. QJM. 2019;113(3):217-8.

5. Yuan R, Yamada A, Weber B, dkk. Radiographic patterns and survival of patients with early and late brain metastases in EGFR wild type and mutant nonsmall cell lung cancer. J Neurooncol. 2016;127:52533.

6. Patil T, Pacheco JM. Miliary metastases in non-smallcell lung cancer. N Engl J Med 2018;379:1945.

7. Bahrami E, Taheri M, Benam M. Calcified brain metastatic adenocarcinoma: A case report and review of the literature. Neuroradiol J. 2018;32(1):57-61.

8. Hsu F, Nichol A, Toriumi T, Caluwe AD. Miliary metastases are associated with epidermal growth factor receptor mutations in non-small cell lung cancer: a population-based study. Acta Oncol. 2017; 56(9):1175-80.

9. Okuma Y, Kashima J, Watanabe K, Homma S. Survival analysis and pathological features of advanced non-small cell lung cancer with miliary pulmonary metastases in patients harboring epidermal growth factor receptor mutations. J Cancer Res Clin Oncol. 2018;144:1601-11.

10. Morin S, Abdallah B, Wong A. Brain metastases in non-small-cell lung cancer: are tyrosine kinase inhibitors and checkpoint inhibitors now viable options? Curr Oncol. 2018;25(S1):S103-14.

11. Joo JW, Hong MH, Shim HS. Clinical characteristics of T790M-positive lung adenocarcinoma after resistance to epidermal growth factor receptortyrosine kinase inhibitors with an emphasis on brain metastasis and survival. Lung Cancer. 2018;121:1217.

12. Yuan R, Yamada A, Weber B, dkk. Radiographic patterns and survival of patients with early and late 
brain metastases in EGFR wild type and mutant nonsmall cell lung cancer. J Neurooncol. 2016;127:52533.

13. Putora PM, Ess S, Panje C, Hundsberger T, VanLeyen K, Plasswilm L, dkk. Prognostic significance of histology after resection of brain metastases and whole brain radiotherapy in non-small cell lung cancer (NSCLC). Clin Exp Metastasis. 2015;32:1439. 